\title{
Available Feed Resources and Nutritive Value of Major Browse Species in East Dembia District, Central Gondar, Ethiopia
}

\author{
MULUYE FEKADE (BSc. Animal Science) MERGA BAYSSA ( PhD) Prof. AJEBU NURFETA (PhD)
}

\begin{abstract}
This study was conducted to assess the available feed resources, identify the most commonly used browse species as livestock feed and to determine their nutritive value from East Dembia district. Four kebeles (Sufankara, Grargie, Salj Gebeba and Atkilit Teleft) were selected purposively. Stratified random sampling was used for the selection of respondents. A total of 12 plots of $20 \mathrm{~m} * 20 \mathrm{~m}\left(400 \mathrm{~m}^{2}\right)$ were established at an interval of $200 \mathrm{~m}$ along the transect line to identify and record the available browse species. The leaves and petioles of A. abyssinica, C. africana, F. thonigii, F. sycomorus, V. amygdolina, M. arbutifolia, and A. seyal were collected for chemical analysis. General linear model procedure of SAS was used for statistical analysis. The mean CP content of the browse species ranged from $12.13 \%$ (F. sycomorus) to $29.74 \%$ (V. amygdolina). The IVDMD varied from $38.5 \%$ for M. arbutifolia to $71.67 \%$ for F. sycomorus. High gas production from immediately soluble component (a) was recorded for C. africana. The gas production from insoluble but potential degradable fraction (b) and production potential $(a+b)$, organic matter digestibility, where high for F. thounigii but low for V. amygdolina. The browse species in the current study could be used as protein supplements to livestock fed on low quality feeds due to their high levels of crude protein, low fiber contents and high digestibility potentials. However, it is recommended that further studies need be undertaken in determining the nutritive value of the other browse components such as pods.
\end{abstract}

Keywords: Browse species, nutritive value, crude protein, in vitro dry matter digestibility

DOI: $10.7176 / \mathrm{JBAH} / 10-13-03$

Publication date:July $31^{\text {st }} 2020$

\section{INTRODUCTION}

\subsection{Background and Justification}

Ethiopia's national economy mainly relay on agriculture, which shares for more than $80 \%$ of income of the population (Alemayehu, 2002). Livestock production is one of the major area in the agricultural sector providing draught power, meat, milk and other products, serves as a source of additional income both for smallholder farmers and livestock owners'(Ehui et al., 2002, Jonah, 2004).

In Ethiopia, Ahmed et al. (2010) indicated that regardless of having ample number of farm animals, its contribution to GDP is limited to $20 \%$ and per unit productivity is quite low. The main bottleneck impediment to such low productivity is insufficient year round livestock feed supply in terms of quantity and quality, particularly during the dry season (EARO, 2000). In the mixed crop-livestock farming systems of the Ethiopian highlands, feed resources accessible for livestock production are obtained from permanent marginal pastures and seasonal pastures between cropping cycles, crop residues, and crop aftermath grazing. However, these feed resources are very low in quality having high fibre, with low to moderate digestibility and low levels of nitrogen (Tsige-Yohanes, 2000). Consequently, such low quality feeds are linked with a low voluntary intake, thus resulting in inadequate nutrient supply, low productivity and even weight loss.

On top of this, it is generally true that population of Ethiopia is increasing very fast. This boosts demands for more arable land to produce more food for humans, which continuously reduces the amount of land accessible for grazing and browsing (Kassahun, 2011).

The livelong insufficient nutrient supply may adversely affect productive performance of animals. In spite of these limitations, marginal pastures and crop residues could offer essential source of energy for ruminant livestock if provided with protein-rich feeds.

This calls for an action to be taken to fill gap and serve as a bridge between the dry and wet seasons. In an effort to lessen the animal feed supply problem, looking for potential feed resources, especially those which survive during the dry season, ought to have due attention. In this view, the use of browse species has great potential and a paramount importance to alleviate the problem of feed supply. Browse species could be used as a short-term measure when the period shifts from wet to dry seasons since they stay green (Teferi, 2006).

Being major sources of animal feeds in Africa, browse species are highly valued by farmers (Teshome et al., 2012). They play a very prominent role in areas where moisture is inadequate (Gelayenew et al., 2016). These browse plants contain appreciable amounts of nutrients that are deficient in other feed resources such as crop residues during dry periods (Megersa et al., 2017). Furthermore, the ability of most browse species to remain green for a longer period is accredited to deep root systems, which enable them to dig up water and nutrients from deep in the soil structure and this contribute to the increased CP content of the foliage (Teferi et al, 2008).

East Dembya district, where this study was carried out, is characterized by mixed crop-livestock production, woyna-dega climatic condition, and sources of ample browse species. Browse species play a key role in providing 
and making a large contribution to livestock nutrition as they depend on such species during dry season. In spite of the availability of the indigenous browse species as livestock feed, little research has so far been done which assessed the extent of its utilization, inventory of the major species and evaluation of the potential nutritive values. Therefore, this study was conducted based on the following general and specific objectives;

\subsection{General Objective}

$>$ To assess the available feed resources and identify the major browse species utilized by livestock and to determine their nutritive value in East Dembia district.

\subsection{Specific Objectives}

$>$ To assess the available feed resources

$>$ To identify the major browse species

$>$ To determine the chemical composition, in vitro gas production and digestibility of the major browse species important as feed for livestock

\section{MATERIALS AND METHODS}

\subsection{Description of the Study Site}

East Dembia district is situated at $37^{\circ} 09^{\prime} 60.00^{\prime \prime}$ E longitude and $12^{\circ} 39^{\prime} 59.99^{\prime \prime} \mathrm{N}$ latitude and bordered with Gondar town and Lay Armachiho in the North, Alefa in the west and part of Lake Tana in the south. Its altitude ranges from 1370 to 1950 meter asl and the main rainy seasons of the area occurs from June to mid of September, while the dry season spells from November to April. The area receives an average annual minimum and maximum rain fall of $700 \mathrm{~mm}$ and $1175 \mathrm{~mm}$, respectively. The daily mean minimum and maximum temperature is $11{ }^{\circ} \mathrm{C}$ and $32{ }^{0} \mathrm{C}$, respectively.

\subsection{Survey Data Collection}

\subsubsection{Data collection techniques and selection of the study site and sampling methods}

Primary and secondary sources were used to collect the data. The actual household survey was conducted from September to late October 2017 with a pre-tested questionnaire. East Dembia district consists of 30 farmer kebeles, out of which 4 kebeles were selected purposively for the study. Those kebeles were selected based on the availability, accessibility and abundance of browse species.

\subsubsection{Household and key informants selection}

A total of 120 respondents were selected by using Yemane's sample size determination formula (Yemane, 1967). $\mathrm{n}=\frac{N}{1+N(\mathrm{e} 2)}$ where, $\mathrm{n}=$ sample size; $\mathrm{N}=$ total number of household and $\mathrm{e}=$ sampling error.

From each kebele 30 farmers who have livestock were selected randomly. In addition, the selection of key informants (KIs) was done through a guided village tour. During the focus group discussion, issues not well indicated by interviewed farmers were clarified and checked.

\subsection{Identification and Sampling of Browse Species}

A reconnaissance survey of the study area was made before the actual data collection. The available browse species were listed and major browse species were ranked according to animal preference and availability at each selected kebele. Along two transects, each $1.5 \mathrm{~km}$ in length, a total of 12 plots were established for the sampling of browse species. At $200 \mathrm{~m}$ interval over the transect line, quadrates of $20 * 20 \mathrm{~m}\left(400 \mathrm{~m}^{2}\right)$ were used for collecting the sample. For plant identification, the common prioritized browse samples were collected from the study sites and made by key informants, knowledgeable farmers, and forage experts. The sample of browses species were collected at the beginning of the dry season (October-end of November).

\subsection{Browse Species Sample Collection and Preparation for Chemical Analysis}

For chemical analysis of the browse species, the sample were hand plucked with a mixture of leaves and petiole (edible parts), a combined sample of 1.5 kilogram on fresh bases from ten plants were used. Parts of the sample were dried at $65{ }^{\circ} \mathrm{C}$ to constant weight for chemical analysis after fresh samples dried under shade. Thereafter, the samples were separately ground in a Willey mill to pass through $1 \mathrm{~mm}$ sieve. Then, the samples were kept in air tight plastic bags pending further analysis.

\subsubsection{Chemical analysis}

All the chemical analyses were performed in Hawassa University, animal nutrition laboratory, except for the CP analysis which was conducted in Debre Birhan research centre. Chemical analyses of browse samples were determined using standard analytical methods. Dry matter and ash contents of samples of browse species were determined according to the procedures of AOAC (2005). Kjeldahl method (AOAC, 2005) was used to determine total nitrogen $(\mathrm{N})$ and crude protein $(\mathrm{CP})$ was calculated as $\mathrm{N}$ x 6.25. Neutral detergent fiber (NDF) was analyzed 
using the detergent extraction method as described by Van Soest et al. (1991) and acid detergent fiber (ADF), and acid detergent lignin (ADL) were analyzed according to Van Soest and Robertson (1985) using Ankom fiber analyzer.

\subsection{In vitro Dry Matter Digestibility}

In vitro dry matter digestibility (IVDMD) of the samples of browse species was determined by the method of Tilley and Terry (1963) as modified by Van Soest and Robertson (1985).

\subsection{In vitro Gas Production}

Samples of the browse species were incubated in vitro with rumen fluid in calibrated glass syringes following the same procedures as of Menke and Steingass (1988).

\subsection{Statistical Analyses}

Survey data was analyzed by using descriptive statistics using SPSS statistical software (SPSS, version 15). Data from the chemical composition, IVDMD, and gas production of most commonly utilized browses were subjected to one-way analysis of variance (ANOVA) procedure using SAS software version 9.2 (SAS, 2002). Significant differences between individual means were declared using the least significant difference (LSD). The model used for the analyses of chemical composition, in vitro dry matter digestibility and in vitro gas production was: Yij $=\mu$ $+\mathrm{bi}+\mathrm{eij}$, where, $\mathrm{Yij}=$ response variable; $\mu=$ overall mean; $\mathrm{bi}=$ browse species and eij= the random error

\section{RESULTS AND DISCUSSION}

\subsection{Dominant browse species}

The browse species in order of relative dominance in the study area is presented in Table 1 . The availability of browse species used as feed for livestock was not the same throughout the study area. In a sense, Maytenus arbutifolia, Acacia seyal and Ficus thounigii were more dominant followed by Vernonia amygdolina and Acacia abysinica.

Table 1. Dominant browse species available

\begin{tabular}{lll}
\hline Species & Index & Rank \\
\hline M.arbutifolia & 0.21 & 1 \\
A. seyal & 0.20 & 2 \\
F. thoungii & 0.19 & 3 \\
V. amygdolina & 0.13 & 4 \\
A. abyssinica & 0.12 & 5 \\
C. africana & 0.07 & 7 \\
F. sycomorus & 0.08 & 6 \\
\hline
\end{tabular}

Index $=$ sum of $(4$ times first order +3 times second order +2 times third order +1 times fourth order) for individual variables divided by the sum of (4 times first order +3 times second order +2 times third order +1 times fourth order) for all variables.

\subsection{Nutritive Values of Browse Species}

\subsubsection{Chemical composition and in vitro dry matter digestibility of browse species}

The chemical composition of the major browse species (leaves and petioles) are presented in Table 2. The ash content varied $(P<0.05)$ among species and range between 7.9 for $M$. arbutifolia to 17.03 for $F$. sycomorus. The ash contents of browse species such as $F$. sycomorus, $F$. thoungii and $C$. africana in this study were relatively high, which implies that the browse species could have high mineral concentrations hence potential as feed supplements to ruminant livestock fed on poor quality roughages.

$\mathrm{CP}$ content varied significantly between species $(P<0.05)$. The mean crude protein content of the browse species ranged between 12.13 for $F$. sycomorus and $29.74 \%$ for $V$. amygdolina. The CP content of browse species obtained in the present study was in accordance with the range (12.5\%-31.9\%) reported by Getachew (2002) in Ginchi watershed Area. Most of the Ethiopian dry forages and roughages analyzed earlier had a CP content of less than $9 \%$, which implies that the microbial requirement can hardly be met unless supplemented with protein rich feeds (Seyoum and Zinash, 1989). Thus, the high CP content in all the evaluated browse species in this study $(12.13-29.74 \%)$ suggested that these species have a potential for supplementing protein to poor quality feeds.

The NDF concentration for the browse species varied $(P<0.05)$ and was between $20.93 \%$ ( . amygdolina) and $47.51 \%$ (C. africana). The NDF value (47.51) for C. africana was lower than the report (54.5) by Belete $e t$ al. ( 2012) while that of M. arbutifolia was slightly higher than the report by the same author. The observed differences in NDF content between species is probably due to the effect of species variability, ability of the soil to supply nutrients to the plant, maturity of the plant (Upreti and Shrestha, 2006), as well as the proportion of different browsed components in the harvested samples. The NDF contents of the browses in the current study lie 
below the critical value of $60 \%$ which was indicated by Reed and Goe (1989), hence may resulting in increased voluntary feed intake, feed conversion efficiency and shorter rumination time.

The IVDM range varied from $38.5 \%$ for $M$. arbutifolia to $71.67 \%$ for $F$. sycomorus. The IVDMD values for F. thoungii (51.09) and F. sycomorus (71.67) were higher than the result obtained by Kassahun (2011). This variation might be due to various factors like harvesting regimen, season and location. The variability in IVDMD of browse species also could be partly due to the differences in CP, NDF, ADF and ADL contents.

Table 2. Mean chemical composition and in vitro dry matter digestibility of browse species (\%DM)

\begin{tabular}{llllllll}
\hline Browse species & Lab DM\% & Ash & CP & NDF & ADF & ADL & IVDMD \\
\hline V.amygdolina & $91.55^{\mathrm{abc}}$ & $12.77^{\mathrm{b}}$ & $29.74^{\mathrm{a}}$ & $20.93^{\mathrm{d}}$ & $12.10^{\mathrm{b}}$ & $3.98^{\mathrm{d}}$ & $47.33^{\mathrm{cd}}$ \\
F. thoungii & $92.55^{\mathrm{ab}}$ & $14.79^{\mathrm{ab}}$ & $15.87^{\mathrm{ef}}$ & $44.69^{\mathrm{ab}}$ & $32.29^{\mathrm{a}}$ & $11.27^{\mathrm{ab}}$ & $51.09^{\mathrm{bc}}$ \\
C. africana & $94.17^{\mathrm{a}}$ & $14.82^{\mathrm{ab}}$ & $18.13^{\mathrm{de}}$ & $47.51^{\mathrm{a}}$ & $32.35^{\mathrm{a}}$ & $13.38^{\mathrm{a}}$ & $65.65^{\mathrm{a}}$ \\
F. sycomorus & $94.61^{\mathrm{a}}$ & $17.03^{\mathrm{a}}$ & $12.13^{\mathrm{f}}$ & $38.76^{\mathrm{abc}}$ & $27.41^{\mathrm{a}}$ & $10.94^{\mathrm{abc}}$ & $71.67^{\mathrm{a}}$ \\
A. seyal & $93.67^{\mathrm{ab}}$ & $9.95^{\mathrm{c}}$ & $20.76^{\mathrm{cd}}$ & $36.72^{\mathrm{bc}}$ & $26.23^{\mathrm{a}}$ & $14.36^{\mathrm{a}}$ & $42.59^{\mathrm{ed}}$ \\
M. arbutifolia & $90.79^{\mathrm{bc}}$ & $7.90^{\mathrm{c}}$ & $27.01^{\mathrm{ab}}$ & $34.60^{\mathrm{bc}}$ & $24.91^{\mathrm{a}}$ & $7.31^{\mathrm{bcd}}$ & $38.5^{\mathrm{e}}$ \\
A. abyssinica & $89.05^{\mathrm{c}}$ & $14.03^{\mathrm{b}}$ & $24.44^{\mathrm{bc}}$ & $32.12^{\mathrm{c}}$ & $16.03^{\mathrm{b}}$ & $4.93^{\mathrm{dc}}$ & $57.14^{\mathrm{b}}$ \\
Mean & 92.34 & 13.04 & 21.15 & 36.48 & 24.48 & 9.45 & 53.42 \\
\hline
\end{tabular}

Column means with different superscript letter is significantly different $(P<0.05)$

\subsubsection{In vitro gas production of major browse species}

Figure 1 shows gas production at various incubation time ( $\mathrm{ml} / 200 \mathrm{mg} \mathrm{DM})$ of the browse species examined. Ficus thoungii had the highest gas production while, Vernonia amygdolina had the lowest. The amount of gas produced when feeds are incubated in vitro has been reported to be closely associated to digestibility of feed for ruminants (Mebrahtu and Tenaye, 1997). Hence, the gas produced can be considered as a good indication of substrate fermentation to VFAs and an estimate of potential digestibility in the rumen. The higher gas production observed for $F$. thoungii, and $M$. arbutifolia therefore suggested that a higher digestibility of these browse species. Babayemi et al. (2004) argued that the variation in gas production probably be due to the variability in nature and level of fibre, potency of the rumen liquor for incubation and the presence of secondary metabolites.

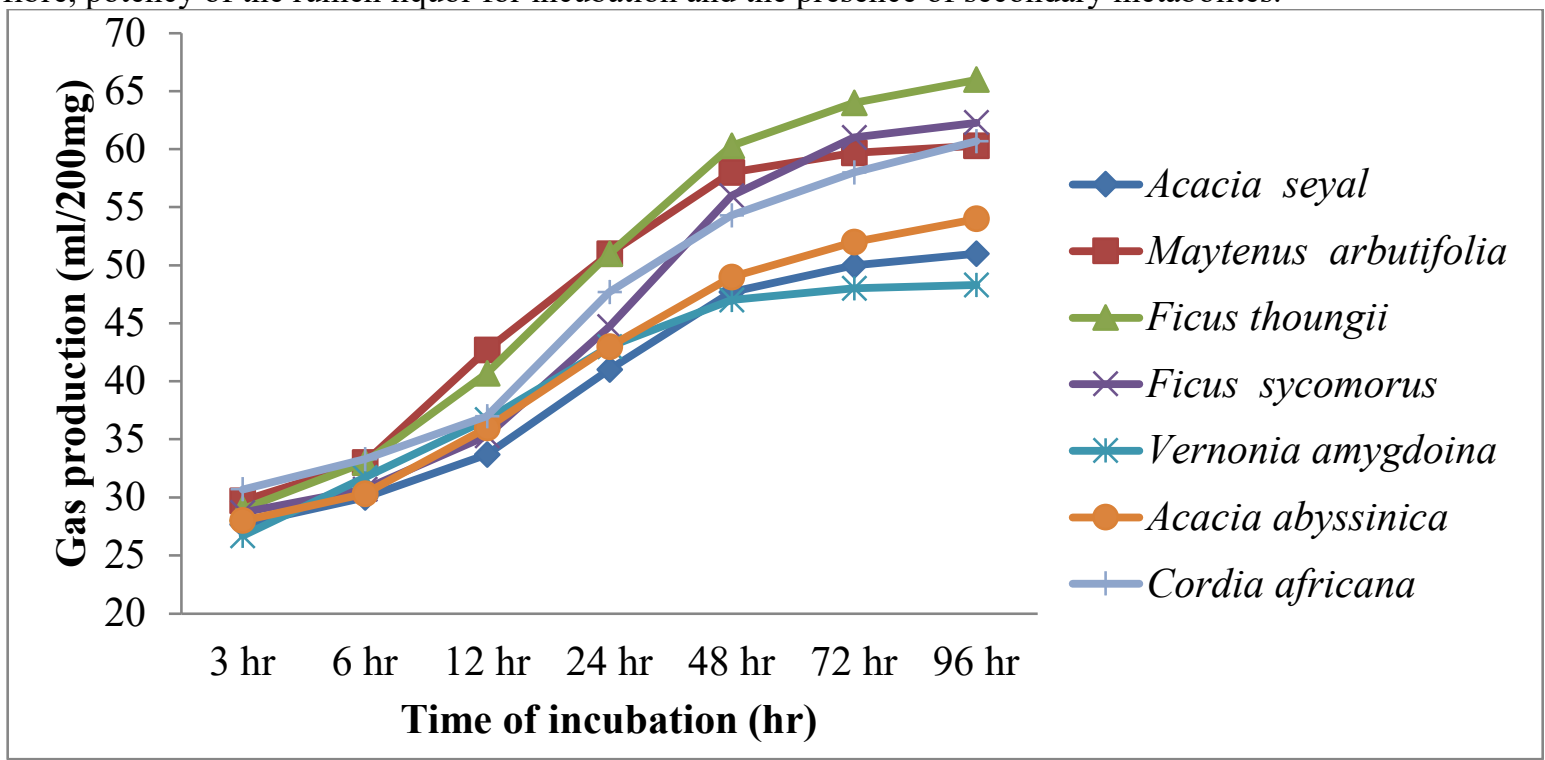

Figure 1. In vitro gas production $(\mathrm{ml} / 200 \mathrm{mg} \mathrm{DM})$ of browse species at different incubation time

In vitro gas production parameters of the major browse species is presented in Table 3. Gas production from immediately soluble component (a) varied from 22.1 for $V$. amygdolina to 26.93 for $C$. africana. Gas production from insoluble but potential degradable portion (b) ranged between 26.1 for $V$. amygdolina and 42.17 for $F$. thoungii. Slowly fermentable fraction ('b' value) of browse species observed in this study was within the range values (18.18-64.93) reported by Mahala and Elseed (2007). The rate of gas production (c) ranged between 0.03 for $C$. africana and $F$. sycomorus and 0.07 for $V$. amygdolina. The gas production potential ranged between 48.16 for $V$. amygdolina and 66.42 for $F$. thoungii. Osuga et al. (2006) argued that variation in potential gas production of the browse species could be attributed to difference in chemical composition, more importantly to $\mathrm{CP}$ and fibre components. 
Table 3. In vitro gas production characteristics of major browse species

\begin{tabular}{lllll}
\hline Browse species & $\mathrm{a}$ & $\mathrm{b}$ & $\mathrm{a}+\mathrm{b}$ & $\mathrm{C}\left(\mathrm{hr}^{-1}\right)$ \\
\hline A. abyssinica & 24.66 & 29.50 & 54.15 & 0.04 \\
A. seyal & 24.52 & 27.83 & 52.35 & 0.04 \\
C. africana & 26.93 & 34.55 & 61.48 & 0.03 \\
F. sycomorus & 24.40 & 41.38 & 65.78 & 0.03 \\
F. thoungii & 24.25 & 42.17 & 66.42 & 0.04 \\
M. arbutifolia & 23.32 & 37.00 & 60.32 & 0.06 \\
V. amygdolina & 22.10 & 26.10 & 48.16 & 0.07 \\
\hline
\end{tabular}

$a=$ gas production from immediately soluble component; $b=$ gas production from insoluble but potential degradable portion; $a+b=$ gas production potential; $c=$ gas production rate constant

3.2.2.1. Organic matter digestibility, short chain fatty acids and metabolisable energy of major browse species

Metabolisable energy (ME), organic matter digestibility (OMD) and short chain fatty acids (SCFA) of the browse species are presented in Table 4. F.thoungii has the highest OMD (\%) and the lowest was recorded for $V$. amygdolina. The OMD obtained in this result was well above the range OMD value (42.2-58.08) reported by Merga et al. (2016) for browse species from Borana rangeland. This inconsistency might be due to differences in fiber fraction (Van, 1994) and organic matter content (Isaac et al., 2008) of the evaluated browse species.

The metabolizable energy content of browse species observed in this study ranged from 7.9 for $A$. seyal to 9.3 for $F$. thoungii. The ME of the present finding was higher than earlier report (4.53-6.48) of Okunade et al. (2014). This disparity probably be due to differences in CP content in addition to other factors for the browse species studied.

F. thoungii has the highest while Acacia seyal recorded the lowest SCFA production amongst the studied browse species. The SCFA observed in the result is by far greater as compared to the finding of Okunade et al., (2014) who indicated that SCFA value of the browse species was ranging between -0.02 and $0.05 \mathrm{mmol} / \mathrm{liter}$. The variation might be due to differences in carbohydrate content of the browse species.

Table 4. Organic matter digestibility, short chain fatty acids and metabolisable energy of major browse species

\begin{tabular}{llll}
\hline Browse species & OMD $\%$ & ME(MJ/kg DM) & SCFA(mmol/L) \\
\hline A. seyal & 63.4 & 7.9 & 0.9 \\
M. arbutifolia & 73.2 & 9.3 & 1.16 \\
F. thoungii & 75.1 & 9.3 & 1.17 \\
F. sycomorus & 70.9 & 8.3 & 1 \\
V. amygdolina & 63.1 & 8.2 & 0.98 \\
A. abyssinica & 64.8 & 8.2 & 0.97 \\
C. africanA & 69.6 & 8.8 & 1.1 \\
\hline
\end{tabular}

OMD $=$ Organic matter digestibility, $M E=$ Metabolisable energy, $S C F A=$ Short chain fatty acid

OMD (\%): OMD (\%) = 18.53+0.9239*Gas production $(48 \mathrm{hrs})+0.0540 *$ Crude protein (Menke \& Steingass, 1988)

$M E(K J / g D M): M E(K J / g D M)=2.20+0.136 *$ Gas production $(24 \mathrm{hrs})+0.0057 *$ Crude protein

SCFA: SCFA + 0.0239*Gas production (at 24 hrs) - 0.0601(Bensalem et al. (2006).

\section{CONCLUSION AND RECOMMENDATIONS}

\subsection{Conclusion}

The present finding revealed that despite having variation in fodder availability and preference, nearly all livestock species consumed browses in the study area. In general, among the browse species evaluated for their nutritional values, some of the species like $M$. arbutifolia and $V$. amygdolina were the browses which have relatively high CP content and consisting low fiber fraction. In the light of this, the browse species can be used as a potential to supplement poor quality feeds such as crop residues, crop stubbles and pasture hay which are common in the study area. Furthermore, the high OMD and ME value of $F$. thoungii and M. arbutifolia, would make the browse potential supplement of low quality roughages.

\subsection{Recommendation}

Apart from chemical composition, further study is recommended to determine biomass yield and nutritive value in terms of methane production and anti-nutritional factors such as tannin content for efficient utilization of the browse species in the future. It is also recommended to conduct feeding and in vivo digestibility trial after appropriate identification from previous similar studies, on the most promising browse species such as $M$. arbutifolia, and V. amygdolina. In addition, parts of browse species used as livestock feed such as pods and other components not considered in the present study should be evaluated for their nutritional qualities. 


\section{REFERENCES}

Ahmed Hassen, Abule Ebro, Mohammed K. U. and Treydte AC. (2010). "Livestock feed resources utilization management as influenced by altitude in the central highlands of Ethiopia". Livestock research for rural development.

Alemayehu Mengistu (2002). "Forage production in Ethiopia: a case study with implications for livestock production". Addis Ababa, Ethiopia. pp.1-3.

AOAC (Official Methods of Analysis) (2005). International.18th ed. Gaithersburg, USA.

Babayemi O. J., Demeyer D., and Fievez V. (2004). "Nutritive value and qualitative assessment of secondary compounds in seeds of eight tropical browse, shrub and pulse legumes". Communications in Agricultural and Applied Biological sciences 69: 103-110.

Belete Shinkute, Hassen Abubeker, Assafa Tadese, Amen Nura and Ebro Abule (2012). "Identification and nutritive value of potential fodder trees and shrubs in the Mid Rift Valley of Ethiopia". The Journal of Animal and Plant Science 22:1126-1132.

Bensalem A.Z.M., Salem M.Z.M., El-Awday M.M and Robinson P.H. (2006). "Nutritive evaluation of some browse tree foliages during the dry season: Secondary compounds, feed intake and in vivo digestibility in sheep and goats". Animal feed science and Technology 127: 251-267.

EARO (Ethiopian Agricultural Research Organization) (2000). "National Small Ruminants" Research Strategy Document. EARO, Addis Ababa, Ethiopia.

Ehui S., Benin S., Williams T. and Meijer S. (2002). "Food security in Sub-Saharan Africa to socioeconomic and policy research working paper" 49, ILRI (International Livestock

Gelayenew Bizelew, Ajebu Nurfeta, Getnet Assefa and Getahun Asebe (2016). "Assessment of livestock feed resources in the farming systems of mixed and shifting cultivation, Gambella regional state, southwestern Ethiopia". Global Journal of Science Frontier Research: Agriculture and Veterinary 16: 5.

Getachew Eshete (2002). "An assessment of feed resources, their management and impact on livestock productivity in the Ginchi watershed area. MSc. Thesis. Haramaya University, Haramaya". 172p.

Isaac M. Osuga, Carolyne C. Wambui, Shaukat A. Abdulrazak, Toshiyoshi Ichinohe and Tsutomu Fujihara (2008). "Evaluation of nutritive value and palatability by goats and sheep of selected browse foliages from semi arid area of Kenya". Animal Science Journal 79:582-589.

Jonah L.B. (2004). "Economics of production and marketing of beef cattle in Efate, Vanuatu. B. Agric. Project". The University of the South Pacific, School of Agriculture, Alafua Campus, Apia, Samoa. pp. 1-4.

Kassahun Desalegn (2011). "Identification and nutritional value assessment of the major browse species utilized by livestock in Chiliga district, north Gondar". M.Sc Thesis. Haramaya University, Haramaya.

Mahala A.G. and A.N.M.A.F. Elseed (2007). "Chemical composition and in vitro gas production characteristics of six fodder trees leaves and seeds". Research Journal of Agriculture and Biological sciences 3(6): 983-986.

Mebrahtu O and Tenaye SB. (1997). "Analytical methods for feeds animal excrements and animal tissues". International Livestock Research Institute (ILRI) nutrition laboratory ILRI-Ethiopia, Addis Ababa, Ethiopia.

Megersa Endiebu, Alemayehu Mengistu, Asebe Getahun (2017). "Nutritional characterization of selected fodder species in Abol and Lare districts of Gambella region, Ethiopia". Journal of Nutrition and Food Science 7:581.

Menke K.H and Steingass H. (1988). "Estimation of the energetic feed value obtained from chemical analysis and in vitro gas production using rumen fluid". Animal Research Development 28:7-55.

Merga Bayssa, Tegene Negesse and Adugna Tolera (2016). "Forage quality and methane reduction potentials of selected browse species from Borana rangeland, Southern Ethiopia". American-Eurasian Journal of Scientific Research $11: 209-223$.

Okunade S.A.; Isah O.A.; Aderinboye R.Y.; Olafadehan O.A. (2014). "Assessment of chemical composition and in vitro degradation profile of some guinea savannah browse plants of Nigeria". Tropical and Subtropical Agro ecosystems 17( 3): 529-538

Osuga I. M., Abdulrazak S. A., Ichinohe T. and Fujihara T. (2006a). "Rumen degradation and in vitro gas production parameters in some browse forages, grasses and maize stover from Kenya". Journal of Food, Agriculture and Environment 4: 60-64.

Reed JA. And Goe MR. (1989). "Estimating the nutritive value of cereal crop residues: implications for developing feeding standards for draught animals". ILCA. Bulletin No. 4 ILCA, Addis

SAS. (2002). "SAS User's Guide Version 9.2; Statistical Analysis Systems Institute. Inc., Cary, NC, USA".

Seyoum Bedye. and Zinash Sileshi (1989). "The composition of Ethiopian feed stuffs, research report no. 6". Institute of Agricultural Research; Addis Ababa, Ethiopia. 33 p.

Teferi Aregawi (2006). "Identification and nutritional value characterization of major browse species in Abergele district, Tigray". M.sc Thesis. Alemaya University, Alamaya.

Teferi Aregawi, Solomon Melaku and Lisanework Nigatu (2008). "Management and utilization of browse species as livestock feed in semiarid district of north Ethiopia". Livestock Research for Rural Development. pp. 2086. 
Teshome Abate, Abule Ebro and Lisanework Nigatu (2012). "Evaluation of woody vegetation in the rangeland of southeast Ethiopia". International Research Journal of Agricultural Science Soil Science 2: 113-126.

Tilley J.M.A. and R. A. Terry (1963). "A two stage technique for in vitro digestion of forage crops". Journal of British Grassland Society 18: 108-112.

Tsige-Yohannes Habte (2000). "Livestock feed security and associated impacts on sustainable agricultural development". In: proceedings of the 7th annual conference of Ethiopian Society of Animal Production (ESAP), Addis Ababa, Ethiopia, 26-27 May. pp.51-61.

Upreti, C. R and Shrestha, B. K. (2006). "Nutrient contents of feeds and fodder in nepal, feedstuff and animal production in nepal". Animal Nutrition Division, NARC Kathmandu, Nepal.

Van Soest P.J., Robertson J.B. and Lewis B.A. (1991). "Methods for dietary fiber, neutral detergent fiber, and non starch polysaccharides in relation to animal nutrition". Journal of Dairy Science 74:3583-3597.

Van Soest P.J. and J.B. Robertson (1985). "Analysis of forage and fibrous foods". A laboratory manual for animal science. 613 Cernell University, New York, USA.

Yemane Taro. (1967). "Statistics: An Introductory Analysis, $2^{\text {nd }}$ Ed., New York: Harper and Row". 